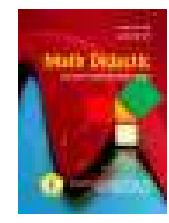

MATH DIDACTIC: JURNAL PENDIDIKAN MATEMATIKA

Volume 6 Nomor 1, Januari - April 2020, halaman 65 - 74

Tersedia Daring pada https://jurnal.stkipbjm.ac.id/index.php/math

\author{
PENINGKATAN KEMAMPUAN MENYELESAIKAN OPERASI PERKALIAN \\ DAN PEMBAGIAN PADA BILANGAN PECAHAN SISWA KELAS VB \\ SDN INDRASARI 2 MARTAPURA MELALUI LATIHAN BERJENJANG
}

\title{
IMPROVEMENT OF ABILITY OF CLASS VB STUDENTS \\ SDN INDRASARI 2 MARTAPURA TO SOLVE MULTIPLYING AND DIVIDING FRACTION USE TIERED DRILLING
}

\author{
Halawati, Mayang Gadih Ranti \\ SDN Indrasari 2 Martapura, STKIP PGRI Banjarmasin \\ halawati.nasymida@gmail.com, mayanggadih@stkipbjm.ac.id
}

\begin{abstract}
Abstrak. Perkalian dan pembagian bilangan pecahan sering kali menjadi persoalan yang sulit bagi siswa SD. Siswa mengalami kesulitan melakukan pekerjaan hitungan atau kalkulasi pada bilangan pecahan, khususnya pada pembagian. Hal yang sama dialami oleh siswa kelas VB SDN Indrasari 2 Martapura yang kesulitan menghitung hasil perkalian dan pembagian pecahan. Untuk mengatasi kesulitan tersebut digunakan metode latihan berjenjang, mengingat karakteristik siswa yang memerlukan latihan yang terkoordinasi dari konsep dasar menginjak ke materi selanjutnya secara berjenjang dari sederhana ke kompleks. Penelitian ini bertujuan untuk mengetahui peningkatan aktivitas dan kemampuan siswa dalam perkalian dan pembagian bilangan pecahan kelas VB SDN Indrasari 2 Martapura melalui pembelajaran dengan metode latihan berjenjang. Metode Penelitian yang digunakan adalah Penelitian Tindakan Kelas (PTK). Subjek penelitian ini adalah siswa kelas VB SDN Indrasari 2 Martapura sebanyak 21 orang. Data aktivitas dan hasil belajar dikumpulkan melalui observasi dan tes dan dianalisis menggunakan rata-rata dan persentase. Hasil penelitian menunjukkan aktivitas siswa meningkat dari Siklus I ke Siklus II dari cukup aktif ke sangat aktif dan kemampuan siswa dalam perkalian dan pembagian bilangan pecahan meningkat dari baik ke sangat baik.
\end{abstract}

Kata Kunci: kemampuan siswa, operasi perkalian dan pembagian pecahan, latihan berjenjang

Abstract. Multiplying and dividing fractions often become a complicated problem for elementary school students. Students have difficulty doing fraction computation on, especially on dividing fractions. The same thing happens to students of class VB SDN Indrasari 2 Martapura, who has a problem solving multiplying and dividing fractions. The effort used to solve the problem is by using a tiered drilling method. It was done because the characteristic of students who needs a structured drill which started from a simple to a complex problem. The research aims to know the improvement of activity and ability to multiplying and dividing fraction of students' class VB SDN Indrasari 2 Martapura by learning using tiered drilling. The research method was action research. The research subjects were 21 students of class VB SDN Indrasari 2 Martapura Data was collected by Observation and test and analyzed using averages and percentages. The research subjects were student's activity and ability to solve multiplying and dividing fractions. The results show that there is an improvement of student's activity from the middle to very active and student's ability to solve multiplying and dividing fraction from high to very high.

Keywords: student's ability, multiplying and dividing fractions, tiered drilling

Cara Sitasi: Halawati, H., \& Ranti, M. G. (2020). Peningkatan kemampuan menyelesaikan operasi perkalian dan pembagian pada bilangan pecahan siswa kelas VB SDN Indrasari 2 Martapura melalui latihan berjenjang. Math Didactic: Jurnal Pendidikan Matematika, 6(1), 65-74. https://doi.org/10.33654/math.v6i1.911

Submitted: January 23, 2020

Revised: April 28, 2020

Published: April 30, 2020

Available Online Since: April 29, 2020

https://doi.org/10.33654/math.v6i1.911

Math Didactic: Jurnal Pendidikan Matematika 
Siswa di SDN Indrasari 2 Martapura mengalami kesulitan dalam belajar, khususnya ketika menyelesaikan perkalian dan pembagian pecahan. . Kesulitan dalam belajar yang dihadapi siswa mengakibatkan kendalakendala pada pembelajaran, terutama memahami materi dalam matematika yang objeknya abstrak dan banyak prosedurprosedur yang berkaitan satu sama lain. Kendala-kendala ini mengakibatkan siswa menjadi tidak fokus dan terkesan bosan dengan pembelajaran matematika, yang tentunya akan berimbas pada rendahnya hasil belajar siswa. Hasil ulangan formatif Tahun Ajaran 2017/2018 menunjukkan masih banyak anak yang belum mampu menuntaskan materi tersebut. Rata-rata nilai siswa untuk materi perkalian dan pembagian bilangan pecahan adalah 60. Nilai ini masih jauh berada di bawah Kriteria Ketuntasan Minimal (KKM), yaitu 70. Ini artinya, kemampuan siswa pada materi perkalian dan pembagian pecahan masih perlu ditingkatkan. Padahal materi ini menjadi dasar untuk materi-materi selanjutnya.

. Matematika tidak hanya fokus pada masalah dalam kehidupan sehari-hari tetapi juga menggunakan imajinasi, intuisi dan penalaran untuk menemukan ide-ide baru dan menyelesaikan masalah-masalah yang membingungkan (Khan, 2015). Matematika sebelumnya dipandang oleh sebagian besar orang sebagai tubuh ilmu pengetahuan yang statis dan tetap. Domain matematika sendiri adalah bilangan, geometri, kuantitas, statistik dan Aljabar (Romberg \& Kaput, 2009).

Matematika merupakan ilmu terstruktur yang mana materi yang satu dan materi yang lainnya saling berkaitan. Materi yang satu akan menjadi materi prasyarat oleh materi berikutnya. Oleh karena itu, pembelajaran matematika harus dilakukan secara sistematis dan terurut. Matematika diajarkan sesuai dengan jenjangnya dan berurutan satu dengan yang lainnya.

Selain matematika yang memiliki karakteristik tersendiri, anak pada usia Kelas V SD, yaitu usia sekitar $10-11$ tahun juga memiliki karakteristik yang istimewa. Pada tahap usia ini, anak mulai memiliki rasa ingin tahu yang besar dan mulai memasuki tahap pemikiran yang lebih kompleks. Unsur kemandirian Belajar juga sudah mulai terlihat. Pada umumnya, kemampuan kognitif anak usia dasar memiliki keterbatasan berpikir terhadap hal yang bersifat abstrak. Anak akan mengalami kesulitan bahkan merasa kebingungan untuk menjawab pertanyaan yang demikian secara ilmiah, justru anak akan merasa stres, karena kemampuan kognitifnya belum sampai pada tahap berpikir yang rumit (Bujuri, 2018).

Kesulitan anak dalam menerjemahkan hal-hal yang bersifat abstrak karena mereka masih terbiasa dengan konsep-konsep pembelajaran tematik yang telah mereka peroleh di kelas-kelas sebelumnya, dimana pembelajaran selalu dikaitkan dengan hal-hal konkret yang ada di sekitar mereka. Mereka terbiasa dengan pembelajaran yang di dalamnya dihadirkan benda-benda yang ada di sekitar mereka, bukan sesuatu yang harus mereka bayangkan dalam pikiran. Pengetahuan diperoleh melalui proses menghubungkan objek yang ada di dunia nyata dengan konsep yang ada dipikirkan. Anak akan mengubah dari sesuatu yang konkret menjadi suatu konsep yang abstrak.

Begitu juga dalam pembelajaran matematika di Sekolah Dasar. Pada tingkat yang lebih tinggi, siswa akan dihadapkan pada materi yang memiliki konsep yang bersifat abstrak. Tujuan pembelajaran matematika di Sekolah Dasar sendiri adalah membekali siswa dengan kemampuan berhitung yang meliputi 
kemampuan penjumlahan, pengurangan, perkalian, pembagian, pengukuran sederhana dan pemahaman bentuk geometris (Anwar, 2012).

Melihat kondisi di atas dapat dianalisis bahwa kesulitan dalam memahami konsep perkalian dan pembagian bilangan pecahan ini cenderung disebabkan oleh kesulitan anak dalam menerjemahkan hal-hal yang bersifat abstrak dalam matematika ke dalam bentukbentuk konkret. Berdasarkan wawancara dengan guru Kelas V SD dan observasi pembelajaran yang dilakukan, pembelajaran yang ada belum memberi pengalaman konkret yang tepat bagi siswa sehingga siswa kesulitan memahami konsep yang ada. Selain itu strategi pembelajaran yang diberikan guru cenderung kurang tepat, dimana siswa belum diberi kesempatan untuk mengelola pembelajaran sendiri maupun di dalam kelompoknya dan kurangnya memberikan latihan secara berjenjang.

Untuk mengatasi permasalahan tersebut, maka diperlukan metode pembelajaran yang dapat menjembatani sesuatu yang abstrak dalam matematika dengan hal-hal konkret dalam kehidupan siswa. Selain itu, siswa harus dilatih berpikir secara sistematis dan terurut agar memudahkan dalam memahami materi-materi yang bersifat prosedural atau keterampilan seperti materi perkalian dan penjumlahan bilangan pecahan.

Metode pembelajaran alternatif yang dapat digunakan dalam membantu siswa dalam memahami pengoperasian perkalian dan pembagian bilangan bulat adalah dengan metode latihan (drill) berjenjang. metode ini sesuai untuk siswa yang memerlukan latihan yang terkoordinasi dimana proses pembelajaran dari konsep dasar menginjak ke materi selanjutnya disajikan secara berjenjang dari yang sederhana ke kompleks, sehingga siswa lebih mudah memahaminya.

Metode latihan berjenjang merupakan suatu metode mengajar dimana siswa diberikan soal-soal latihan secara terstruktur dari yang mudah ke yang sulit, atau dari yang sederhana ke yang kompleks. Metode latihan masih dipercaya sebagai metode yang reliabel untuk pengetahuan-pengetahuan tertentu dan dipraktikkan pada subjek berbasis latihan yang berisi prosedur-prosedur proses (Kani \& Sa'ad, 2015). Metode latihan (drill) adalah suatu metode yang mendorong siswa untuk melaksanakan kegiatan latihan secara berulang-ulang dan terus menerus untuk menguasai suatu kemampuan atau keterampilan tertentu.

Tujuan dari metode latihan berjenjang adalah mendorong siswa menjadi terlatih mengerjakan soal-soal yang bersifat prosedural. Selain terlatih mengerjakan soalsoal prosedural, penyajian soal-soal yang terstruktur dari yang mudah ke yang sulit dapat membuat siswa lebih mudah menemukan konsep-konsep baru karena telah memiliki konsep-konsep sebelumnya yang lebih kuat. Kelebihan metode latihan berjenjang juga dapat membuat siswa menjadi lebih aktif, karena mereka terlibat langsung dalam penyelesaian soal-soal yang diberikan dan menjadi merasa tertantang untuk menyelesaikan soal-soal yang ada.

Metode drill atau latihan secara berjenjang adalah drill atau latihan yang dilakukan secara berjenjang, yaitu dimulai dari pengerjaan soal-soal yang sederhana hingga ke soal yang kompleks. Pada awal pembelajaran, diberikan materi dilanjutkan pengerjaan soal secara terurut dan sistematis dikerjakan oleh siswa secara mandiri atau berkelompok sehingga menjadi mahir dan terampil. Pengerjaan latihan berjenjang dapat 
mendorong siswa mengorganisir pengetahuan dan keterampilan, serta dapat membuat siswa menjadi lebih mandiri.

Metode drill seharusnya dapat melatih kecakapan dalam memahami dan menginterpretasi kemudian menuliskan strategi dengan prosedur yang tepat sesuai prinsip dan konsep, menggambar grafik, dan menuliskan notasi, istilah ataupun persamaan dengan lengkap dan benar (Primayanti et al., 2018). Metode drill cocok diterapkan untuk materi yang bertujuan membekali siswa dengan pengetahuan dan keterampilan, seperti perkalian dan pembagian bilangan pecahan.

Dalam pembelajaran matematika, materi yang satu dan materi yang lain tidak jarang saling berkaitan satu sama lain. Materi dalam matematika terstruktur dan pembelajaran matematika juga akan lebih mudah jika dimulai dari materi yang sederhana ke materi yang kompleks. Metode latihan berjenjang adalah metode drill atau latihan yang mana pada penerapannya terkoordinasi dari konsep dasar menginjak ke materi selanjutnya secara berjenjang dari sederhana ke kompleks, sehingga siswa lebih memahami.

Pecahan adalah bilangan yang mewakili keseluruhan. Pecahan juga merupakan bagian kecil dari keseluruhan. Pecahan $\frac{a}{b}$ terdiri dari pembilang $(a)$ dan penyebut $(b)$. Pecahan juga merupakan bilangan yang menyatakan proporsi dua bilangan. Pada zaman modern tampaknya ada peningkatan kebutuhan pengukuran panjang, waktu, berat dan hal lainnya yang lebih akurat. Peningkatan ini memerlukan tingkat keakuratan yang berarti bahwa penggunaan skala unit pengukuran yang lebih kecil diperlukan. Pecahan digunakan dalam kehidupan sehari-hari untuk menggambarkan bagian kuantitas (Robertson et al., 2006).
Lebih lanjut, Robertson et al. (2006) menyebutkan ketika mengalikan pecahan, kalikan pembilang dengan pembilang, dan penyebut dengan penyebut. Misalnya $\frac{2}{3} \times \frac{4}{5}=$ $\frac{2 \times 4}{3 \times 5}=\frac{8}{15}$. Jika ingin membagi pecahan, kalikan pecahan dengan kebalikan pecahannya. Kebalikan pecahan $\frac{a}{b}$ adalah $\frac{b}{a}$. Misalnya $\frac{1}{2}: 5=\frac{1}{2} \times \frac{1}{5}=\frac{1 \times 1}{2 \times 5}=\frac{1}{10}$.

Kesulitan siswa dalam menyelesaikan pecahan juga menyebabkan aktivitas pembelajaran yang dilakukan siswa juga rendah. Siswa cenderung pasif dan hanya menerima penjelasan dari guru dan sangat jarang bertanya. Oleh karena itu diperlukan suatu metode pembelajaran yang tidak hanya mendorong meningkatnya hasil belajar, dalam hal ini kemampuan menyelesaikan perkalian, dan pembagian pecahan, tetapi juga dapat mendorong meningkatnya aktivitas siswa.

Tujuan dari penelitian ini adalah untuk mengetahui peningkatan aktivitas dan kemampuan siswa kelas VB SDN Indrasari 2 Martapura dalam Pembelajaran perkalian dan pembagian Pecahan melalui metode Latihan Berjenjang. Dengan adanya alternatif pilihan metode baru, diharapkan guru dan siswa dapat bersama-sama lebih aktif dalam meningkatkan mutu pembelajaran, khususnya pada materi perkalian dan pembagian pecahan

\section{Metode Penelitian}

Penelitian ini merupakan Penelitian Tindakan Kelas (PTK). Penelitian Tindakan Kelas bertujuan memberikan perlakukan atau tindakan guna memecahkan permasalahan yang ada dikelas. . Penelitian Tindakan Kelas adalah proses dimana pendidik memeriksa praktik pembelajaran mereka sendiri secara 
sistematis dan hati-hati menggunakan teknikteknik penelitian (Khasinah, 2013).

Subyek penelitian tindakan kelas ini adalah siswa kelas VB SDN Indrasari 2 Martapura sebanyak 21 orang yang terdiri dari 11 putri dan 10 putra.

Penelitian ini sesuai dengan model Kemmis dan Mc. Taggart (Soesatyo et al., 2013), penelitian tindakan kelas meliputi empat tahap yaitu perencanaan (planning), pelaksanaan (acting), pengamatan (observing), dan Refleksi (reflection).

1. Perencanaan (planning)

Pada tahap perencanaan, dirancang RPP, lembar observasi aktivitas, dan tes kemampuan menyelesaikan perkalian dan pembagian bilangan pecahan. Sesuai dengan hasil observasi awal, maka peneliti merancang pembelajaran yang dapat melatih kemampuan siswa pada materi perkalian pecahan, yaitu melalui metode drill atau latihan berjenjang. Soal latihan disusun dari soal yang paling mudah sampai yang kompleks, sesuai dengan konsep perkalian pecahan yang ingin ditanamkan

2. Pelaksanaan

Pada tahap pelaksanaan, peneliti menerapkan metode latihan berjenjang pada pembelajaran materi perkalian dan pembagian pecahan sesuai dengan yang telah direncanakan. Guru terlebih dulu menjelaskan materi dan memberi contoh pengerjaan, kemudian siswa mengerjakan latihan yang telah disusun secara terstruktur dari yang mudah hingga kompleks baik secara individu maupun berkelompok. Pembelajaran akan dilakukan dalam beberapa siklus sampai indikator keberhasilan penelitian tercapai. Pada setiap akhir siklus akan dilakukan tes hasil belajar.

3. Observasi
Pada tahap observasi, dilakukan pengamatan terhadap aktivitas siswa yang dilakukan oleh satu orang observer. Pengamatan dilakukan terhadap aspek-aspek pengamatan siswa, mulai dari awal pembelajaran hingga akhir pembelajaran pada setiap pertemuan pada setiap siklus.

4. Refleksi

Refleksi dilakukan pada setiap akhir siklus, yaitu analisis perencanaan untuk siklus berikutnya berdasarkan hasil yang diperoleh pada siklus sebelumnya. Berdasarkan hasil data aktivitas siswa dan kemampuan perkalian dan pembagian siswa ditentukan langkah-langkah perbaikan dalam pembelajaran siklus selanjutnya.

Teknik pengumpulan data yang digunakan dalam penelitian ini adalah Observasi dan Tes. Observasi dilakukan untuk memperoleh data aktivitas siswa, dan Tes dilakukan untuk mengetahui kemampuan siswa, dalam hal ini kemampuan kognitif dalam perkalian dan pembagian pecahan. Observasi dilakukan oleh guru lain yang bertugas mengamati aktivitas siswa selama pembelajaran. Instrumen pengumpulan data yang digunakan adalah lembar observasi aktivitas siswa dan tes hasil belajar.

Teknik analisis data yang digunakan dalam penelitian ini adalah rata-rata dan persentase. Untuk data hasil observasi aktivitas, aktivitas siswa dianalisis dengan menghitung rata-rata skor aktivitas siswa menggunakan rumus berikut:

$$
\bar{x}=\frac{\sum x_{i}}{n} \times 100
$$

Keterangan:

$\bar{x}=$ rata-rata skor aktivitas siswa

$\sum x_{i}=$ jumlah skor yang diperoleh

$n=$ jumlah skor maksimum

Nilai rata-rata skor aktivitas siswa kemudian akan dikategorikan sesuai tabel berikut. 


\section{Hasil Penelitian dan Pembahasan}

\begin{tabular}{cc}
\hline $\begin{array}{c}\text { Skor Rata-rata } \\
\text { Aktivitas }\end{array}$ & Kategori \\
\hline $90,99-100,00$ & Sangat Aktif \\
\hline $80,99-89,99$ & Aktif \\
\hline $65,99-79,99$ & Cukup Aktif \\
\hline $55,99-64,99$ & Kurang Aktif \\
\hline $0,00-54,99$ & Sangat Kurang Aktif \\
\hline
\end{tabular}

Untuk data kemampuan menyelesaikan perkalian dan pembagian pecahan, diperoleh melalui hasil tes yang dilakukan di akhir setiap siklus. Nilai Hasil tes seluruh siswa dirataratakan menggunakan rumus berikut:

$$
\bar{x}=\frac{\sum x}{\sum N}
$$

Keterangan: $\quad \bar{x}=$ Nilai rata-rata

$$
\begin{aligned}
& \sum x=\text { Jumlah nilai siswa } \\
& \sum N=\text { Jumlah siswa }
\end{aligned}
$$

Kemudian rata-rata nilai siswa dikategorikan sebagai berikut.

Tabel 2. Kategori Nilai Siswa

\begin{tabular}{cc}
\hline Rentang Nilai & Kategori \\
\hline $81-100$ & Sangat Baik \\
\hline $61-80$ & Baik \\
\hline $41-60$ & Cukup Baik \\
\hline $21-40$ & Kurang Baik \\
\hline $0-20$ & Sangat Kurang \\
\hline
\end{tabular}

Selain itu, data hasil tes siswa juga dihitung persentase siswa yang tuntas atau mencapai KKM untuk mengetahui persentase ketuntasan siswa secara klasikal, yaitu menggunakan rumus:

Persentase $=\frac{\sum \text { siswa yang tuntas belajar }}{\sum \text { seluruh siswa }} \times 100 \%$

Indikator Keberhasilan dalam penelitian ini adalah terjadi peningkatan skor aktivitas dan kemampuan menyelesaikan perkalian dan pembagian bilangan pecahan serta memenuhi kriteria ketuntasan klasikal $\geq$ $75 \%$.

\section{Hasil}

Berdasarkan hasil penelitian yang dilakukan melalui observasi dan tes, diperoleh terjadi peningkatan aktivitas dari Siklus I ke Siklus II dari kategori cukup aktif ke aktif, dan hasil tes menunjukkan kemampuan siswa dalam menyelesaikan perkalian dan pembagian pecahan berada meningkat dari Siklus I dan Siklus II dari kategori Baik ke Sangat Baik. Akan tetapi pada Siklus I, kriteria ketuntasan klasikal $\geq 75 \%$ belum tercapai.

Penelitian pada Siklus I dan Siklus II masing-masing dilakukan sebanyak 2 (dua) kali pertemuan dan pertemuan ketiga digunakan untuk tes evaluasi. Pada tahap perencanaan dirancang RPP dan soal-soal latihan untuk materi perkalian dan pembagian pecahan, dan tes hasil belajar. Pembelajaran dirancang sedemikian rupa agar siswa memahami konsep perkalian dan pembagian pecahan dan materi disajikan secara terstruktur, serta soal-soal latihan yang diberikan disusun secara berjenjang dari yang mudah ke yang kompleks.

Pada tahap pelaksanaan, guru melakukan pembelajaran yang dirancang sesuai RPP dan memberikan soal-soal latihan berjenjang kepada siswa guna memahami konsep pecahan dan mampu mengoperasikan operasi pada pecahan. Siswa diharapkan terampil dan menguasai prosedur mengoperasikan pecahan, serta aktivitas belajar siswa meningkat. Selanjutnya dilakukan observasi terhadap aktivitas siswa. Observasi dilakukan oleh Siti Badiah, S.Pd pada setiap pertemuan di Siklus I dan Siklus II. Selain itu, pada setiap akhir siklus dilakukan tes untuk mengukur kemampuan menyelesaikan perkalian dan pembagian pecahan yang dimiliki siswa. 
Berdasarkan hasil observasi yang dilakukan oleh observer diperoleh skor ratarata aktivitas pada Siklus I dan Siklus II masing-masing pada tabel berikut.

Tabel 3. Rata-rata Aktivitas Siswa di Siklus I dan II

\begin{tabular}{ccc}
\hline Siklus & $\begin{array}{c}\text { Rata- rata } \\
\text { Aktivitas } \\
\text { Siswa }\end{array}$ & Kategori \\
\hline I & 79,37 & Cukup Aktif \\
II & 91,63 & Sangat Aktif \\
\hline Rata-rata & 85,5 & \\
\hline
\end{tabular}

Berdasarkan hasil di atas, diperoleh terjadi peningkatan aktivitas siswa dari cukup aktif ke sangat aktif. Pada Siklus I, siswa cenderung masih belum terbiasa mengerjakan soal-soal latihan terstruktur namun sudah terlihat aspek kemandirian dan keingintahuan siswa, sedangkan pada Siklus II siswa sudah mulai terbiasa dengan pengerjaan soal-soal latihan sehingga sebagian besar siswa terlihat bersemangat mengerjakan soal-soal yang diberikan. Peningkatan aktivitas siswa dari Siklus I dan II dapat dilihat pada diagram berikut.

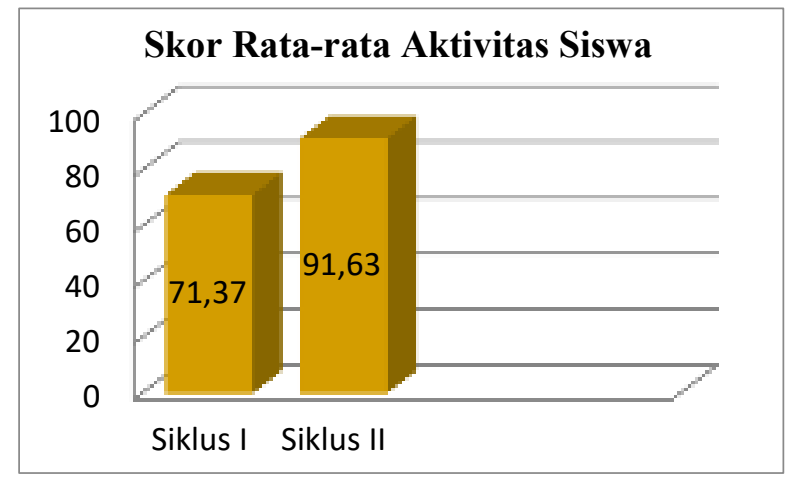

Gambar 1. Diagram Skor Rata-rata Aktivitas Siswa Siklus I dan Siklus II

Pada hasil belajar juga mengalami peningkatan. Berdasarkan hasil tes di setiap akhir siklus diperoleh nilai kemampuan menyelesaikan operasi perkalian dan pembagian pecahan siswa kelas VB SDN Indrasari pada Siklus I dan Siklus II sebagai berikut.

Tabel 4. Rata-rata Hasil Tes Belajar Siklus I dan II

\begin{tabular}{ccc}
\hline Siklus & $\begin{array}{c}\text { Rata-rata } \\
\text { Nilai }\end{array}$ & Kategori \\
\hline I & 77,8 & Baik \\
II & 85,2 & Sangat Baik \\
\hline Rata-rata & 81,5 & \\
\hline
\end{tabular}

Pada Siklus I, hasil tes belajar siswa sudah berada pada kategori baik. Akan tetapi, ketuntasan secara klasikal di Siklus I belum mencapai 75\%. Ketuntasan klasikal di Siklus I masih $71,4 \%$, dimana hanya 15 orang dari 21 siswa yang mencapai nilai KKM, sehingga penelitian dilanjutkan ke Siklus II. Pada Siklus II, rata-rata nilai tes belajar siswa mengalami peningkatan dan ketuntasan secara klasikal tercapai, yaitu sebesar $85,71 \%$, yaitu 18 orang dari 21 orang yang tuntas. Peningkatan kemampuan menyelesaikan perkalian dan pembagian pecahan dapat dilihat pada gambar berikut.

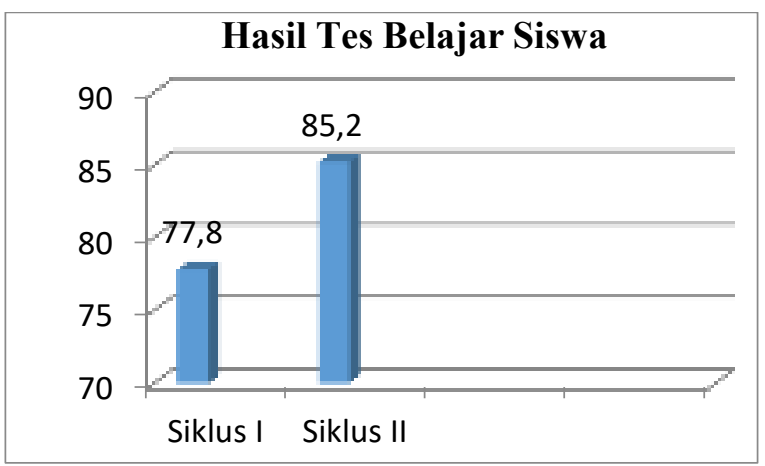

Gambar 2. Diagram Hasil Tes Belajar Siswa Siklus I dan Siklus II

Hasil refleksi tahap I adalah belum tercapainya ketuntasan secara klasikal. Hal ini disebabkan metode latihan diberikan masih terfokus pada pengerjaan secara individu, sehingga masih ada beberapa siswa yang belum mampu menyelesaikan operasi hitung 
pada pecahan dan memperoleh nilai yang rendah. Pada siklus selanjutnya, guru mengarahkan siswa untuk berdiskusi dengan teman yang lain dalam mengerjakan latihan, sehingga kemampuan siswa merata dan ketuntasan secara klasikal dapat tercapai.

\section{Pembahasan}

Berdasarkan gambar tersebut di atas terlihat bahwa hasil observasi dan evaluasi terjadi peningkatan yang cukup signifikan dari Siklus I ke Siklus II, maka pemecahan masalah yang dirasa tepat untuk mengatasi masalah siswa di kelas VB yang berkenaan dengan operasi hitung pecahan perkalian dan membagi melalui Latihan Berjenjang. Hal tersebut didukung oleh kajian pustaka yakni sehubungan dengan karakteristik siswa usia kelas V SD yang mulai belajar dan senang berkelompok dan bermain maka guru menangkap hal tersebut untuk mengelola pembelajaran melalui Latihan Berjenjang.

Selain itu karena melalui Latihan Berjenjang ini memiliki kelebihan-kelebihan diantaranya Siswa lebih mandiri, berpikir sendiri dengan banyak melakukan kegiatan latihan dari hal yang mudah ke hal yang sulit dan bisa mencari tambahan informasi sendiri. Hal ini juga sesuai dengan yang diungkapkan Lesmana et al. (2016) yang menyatakan kelebihan metode latihan adalah akan membuat proses pembentukan pengetahuan dan penyelesaian yang dimiliki siswa menjadi lebih tepat dan cepat. Pembentukan kebiasaan membuat gerakan-gerakan yang kompleks dan rumit menjadi otomatis (habitation makes complex movement more automatic). Dengan sering mengerjakan soal latihan berjenjang, siswa menjadi terbiasa mengerjakan perhitungan-perhitungan perkalian dan pembagian pecahan secara otomatis.

Dengan proses pembiasaan, materi pecahan yang dianggap kebanyakan siswa sulit dapat menjadi lebih mudah. Materi pecahan sendiri merupakan materi yang tergolong sulit bagi siswa SD. Seperti yang diungkapkan Dewi et al. (2014) bahwa materi pecahan merupakan yang cukup sulit dan membutuhkan pemikiran mendalam dari siswa. Konsep pecahan merupakan konsep yang abstrak yang cukup menyulitkan bagi siswa.

Melalui latihan berjenjang, siswa dapat lebih mudah menemukan konsep, karena siswa adanya soal-soal terstruktur yang diberikan memandu siswa untuk menemukan konsep yang berasal dari konsep-konsep yang mereka miliki sebelumnya. Siswa akan lebih mudah mengorganisir pemikirannya karena mengerjakan soal dari yang mudah ke sulit. Ini juga penting dengan adanya latihan berjenjang, siswa dapat lebih percaya diri dan termotivasi dalam pembelajaran, karena merasa telah berhasil mengerjakan soal yang lebih mudah.

Selain itu, pembelajaran dengan metode latihan berjenjang juga meningkatkan aktivitas belajar siswa. Hal ini karena siswa merasa tertantang dengan soal-soal yang diberikan dan memiliki rasa ingin tahu memecahkan soal-soal yang diberikan. Latihan juga mendorong aktivitas kognitif dan psikomotorik siswa menjadi berkembang.

Hasil ini sejalan dengan penelitian Kusumawati \& Irwanto (2016) yang memperoleh bahwa dengan penerapan metode pembelajaran dril, kemampuan pemecahan masalah matematis siswa kelas VIII H SMPN 5 Banjarmasin dapat ditingkatkan. Metode drill juga dapat membuat siswa menjadi lebih berani dan percaya diri dalam pembelajaran.

Proses yang berulang-ulang membuat aktivitas siswa meningkat dan terbiasa mengerjakan soal perhitungan perkalian dan pembagian bilangan pecahan, sehingga 
kemampuannya menjadi meningkat.

\section{Kesimpulan dan Saran}

\section{Simpulan}

Berdasarkan hasil yang diperoleh dari penelitian tindakan kelas dapat disimpulkan sebagai berikut Aktivitas belajar siswa kelas VB SDN Indrasari 2 Martapura melalui Metode Latihan Berjenjang mengalami peningkatan dari Siklus I ke Siklus II dari kategori cukup aktif menjadi sangat aktif. Kemampuan perkalian dan pembagian bilangan pecahan siswa juga meningkat dari Siklus I ke Siklus II yaitu dari kategori tinggi ke sangat tinggi. Ketuntasan secara klasikal tercapai pada Siklus II.

\section{Saran}

Berdasarkan kesimpulan dapat dikemukakan saran-saran yaitu bagi siswa dapat meningkatkan kemampuan menyelesaikan perkalian dan pembagian pecahan atau kemampuan prosedural lainnya melalui memperbanyak latihan, Bagi guru dapat memanfaatkan penelitian untuk memperbaiki pembelajaran yang dikelolanya agar diperoleh proses belajar mengajar yang lebih baik dan bagi peneliti lainnya dapat menjadi wawasan dan acuan untuk penelitianpenelitian lanjutan guna meningkatkan kemampuan matematis siswa lainnya.

\section{Daftar Pustaka}

Anwar, Z. (2012). Pelaksanaan Pembelajaran Matematika di Sekolah Dasar. Jurnal Penelitian Ilmu Pendidikan, 5(2), 24-32.

Bujuri, D. A. (2018). Analisis Perkembangan Kognitif Anak Usia Dasar dan Implikasinya dalam Kegiatan Belajar
Mengajar. LITERASI (Jurnal Ilmu Pendidikan), $\quad 9(1), \quad 37$. https://doi.org/10.21927/literasi.2018.9(1 ).37-50

Dewi, N. C. S., Karlimah, K., \& Nurdin, S. (2014). 2014. Pedadidaktika, 1(2), 8695.

Kani, U. M., \& Sa'ad, T. U. (2015). Drill as a Process of Education. European Journal of Business and Management, 7(21), 175.

Khan, L. A. (2015). What is Mathematics - an Overview. International Journal of Mathematics and Computational Science, 1(3), 98-101. https://doi.org/10.13140/RG.2.1.3626.89 67

Khasinah, S. (2013). Classroom Action Research. Jurnal Pionir, Volume 1, Nomor 1, 1(2), 33-61. https://doi.org/10.17977/um013v1i42017 p156

Kusumawati, E., \& Irwanto, R. A. (2016). Penerapan Metode Pembelajaran Drill untuk Meningkatkan Kemampuan Pemecahan Masalah Matematis Siswa Kelas VIII SMP. EDU-MAT: Jurnal Pendidikan Matematika, 4(1), 49-57. https://doi.org/10.20527/edumat.v4i1.22 89

Lesmana, F., Kusman, M., Ariyano, A., \& Karo, U. (2016). Metode Latihan (Drill) Untuk Meningkatkan Hasil Belajar Peserta Didik Dalam Menggambar Autocad1. Journal of Mechanical Engineering Education, 1(2), 246. https://doi.org/10.17509/jmee.v1i2.3809

Primayanti, G., Suwu, S. E., \& Appulembang, O. D. (2018). Penerapan Metode Drill Untuk Meningkatkan Kemampuan Komunikasi Matematis Siswa Kelas VIII SMP Lentera Way Pengubuan Pada Topik Persamaan Garis Lurus [the 
Implementation of the Drill Method To Increase Mathematical Communication Skills of Grade 8 Students. JOHME: Journal of Holistic Mathematics Education, $\quad 1(2), \quad 135$. https://doi.org/10.19166/johme.v1i2.867

Robertson, D., Cribb, P., Sotiriou, V., \& Waud, E. (2006). Essential Mathematics VELS Edition Year 7. Cambridge University Press.

Romberg, T. A., \& Kaput, J. J. (2009). Mathematics Classroom that Promote Understanding. In Mathematics Worth Teaching, Mathematics Worth Understanding. Lawrence Erlbarum Associates Publisher.

Soesatyo, Y., Subroto, W. T., Sakti, N. C., Edwar, M., \& Trisnawati, N. (2013). pelatihan penulisan proposal peneliti tindakan (PTK) bagi guru ekonomi kabupaten Sidoarjo. Journal of Chemical Information and Modeling, 53(9), 16891699.

https://doi.org/10.1017/CBO9781107415 324.004 